\title{
Connexins-Based Hemichannels/Channels and Their Relationship with Inflammation, Seizures and Epilepsy
}

\author{
Laura Medina-Ceja ${ }^{1, * \mathbb{D}}$, Juan C. Salazar-Sánchez ${ }^{1}$, Jorge Ortega-Ibarra ${ }^{2}$ and \\ Alberto Morales-Villagrán ${ }^{2}$ \\ 1 Laboratory of Neurophysiology, Department of Cellular and Molecular Biology, CUCBA, \\ University of Guadalajara, Guadalajara, Jalisco 45110, México; ss_juan_carlos@hotmail.com \\ 2 MexBio Research Innovations S.A. de C.V., El Salto, Jalisco 45696 México; jaguarjmo@gmail.com (J.O.-I.); \\ amorales56@gmail.com (A.M.-V.) \\ * Correspondence: lauramedcej@gmail.com or laura.mceja@academicos.udg.mx; \\ Tel.: +5233-37771191 (ext. 33201); Fax: +5233-37771191
}

Received: 3 October 2019; Accepted: 20 November 2019; Published: 27 November 2019

\begin{abstract}
Connexins (Cxs) are a family of 21 protein isoforms, eleven of which are expressed in the central nervous system, and they are found in neurons and glia. Cxs form hemichannels (connexons) and channels (gap junctions/electric synapses) that permit functional and metabolic coupling between neurons and astrocytes. Altered Cx expression and function is involved in inflammation and neurological diseases. Cxs-based hemichannels and channels have a relevance to seizures and epilepsy in two ways: First, this pathological condition increases the opening probability of hemichannels in glial cells to enable gliotransmitter release, sustaining the inflammatory process and exacerbating seizure generation and epileptogenesis, and second, the opening of channels favors excitability and synchronization through coupled neurons. These biological events highlight the global pathological mechanism of epilepsy, and the therapeutic potential of Cxs-based hemichannels and channels. Therefore, this review describes the role of Cxs in neuroinflammation and epilepsy and examines how the blocking of channels and hemichannels may be therapeutic targets of anti-convulsive and anti-epileptic treatments.
\end{abstract}

Keywords: connexins; epilepsy models; gliotransmitters; interleukins; neuroinflammation; seizures

The goal of the present review is to clarify the importance of connexins (Cxs) in Cxs-based channels (gap junctions/electric synapses) and hemichannels (connexons), in neuroinflammation, and their relationship with seizures and epilepsy. This review is focused on classic and up-to-date studies of seizure and epilepsy models, to which neuroinflammation and Cxs-based channels and hemichannels are relevant. The first part of this review takes into account information about the molecular and cellular characteristics of Cxs-based channels/hemichannels, as well as their principal functions in neurons and glial cells. The second part describes their relationship with neuroinflammation. The third part discusses how some blockers of channels and hemichannels may be therapeutic targets of anti-convulsive and anti-epileptic treatments, in different models of seizures and epilepsy.

\section{Molecular and Cellular Characteristics of Connexins-Based Hemichannels and Channels}

Connexins (Cxs) are a family of 21 protein isoforms, and some studies have shown that some of these structural proteins in Cx-based channels and hemichannels have an average half-life of 2-3 $\mathrm{h}[1,2]$. Of these isoforms, eleven of them are expressed in the central nervous system (CNS), and are found in neurons and glia. The principal Cxs associated with neurons are Cx45 and Cx36 [3]. In astrocytes, Cx43 
is the most important $C x$, but $C \times 26$ and $C \times 30$ are also expressed [3-5]; $C \times 29, C \times 32, C \times 45$, and $C \times 47$ are expressed in oligodendrocytes [6,7], and Cx32, Cx36, and Cx43 are expressed in microglia [8-10].

Homomeric connexons or hemichannels are formed by six of the same $\mathrm{Cx}$ isoforms, and with different $\mathrm{Cx}$ isoforms, form a heteromeric connexon or hemichannel; two hemichannels in two neighboring cells form a gap junction channel with an aqueous pore diameter of $1 \mathrm{~nm}$ [11], and charged surface walls that depend on the Cx type [12]. These channels, through which cells are electrically and chemically coupled, can be formed from homomeric or heteromeric hemichannels, and are therefore called homotypic or heterotypic channels, respectively. The conductance of these Cxs-based channels and hemichannels is regulated by calcium concentration [13,14], intracellular pH [15-18], some neurotransmitters, such as serotonin and dopamine [19,20], the trans-junctional voltage (relative voltage difference between coupled cells), and the membrane voltage [21,22]. The conductance is related to the type of Cxs that make up the channels and hemichannels; for example, Cx36 has a conductance of 10-15 pS, while Cx45 and Cx43 have a conductance of $27.84 \pm 0.25 \mathrm{pS}$ [23-25] and $36.8 \pm 0.54 \mathrm{pS}$ [25], respectively.

Experimental evidence has demonstrated the presence of Cxs-based channels and hemichannels in important brain regions susceptible to seizure generation, such as the hippocampus, amygdala, and neocortex [3,26-30]. Cxs-based channels are localized between the axons of principal neurons [31], between interneurons with a principally dendrodendritic localization [26], and in neurons with mixed chemical/electrical synapses [32,33]. The principal function of Cxs-based hemichannels is the release of gliotransmitters via a $\mathrm{Ca}^{2+}$-dependent mechanism [13], while channels participate in the propagation of $\mathrm{Ca}^{2+}$ waves, with long-range coupling of the astrocytic network [5]; in neurons, they participate in the synchronization and generation of oscillations in the gamma range (through interneurons dendrites) and ripple frequency (through pyramidal cell axons) [30,31].

\section{Connexins-Based Hemichannels/Channels and Neuroinflammation}

Neuroinflammation is the response to injury, the normal aging process, dementia, stroke, hypertension, depression, diabetes, tumors, infections, toxins, drugs, acute trauma, or neurodegenerative disease that involves the coordination of inflammatory cells, and biochemical activities that occur in the CNS [34-37]. Events associated with neuroinflammation include the activation of astrocytes and microglia, the participation of oligodendrocytes and other nervous system cells, the release of cytokines and chemokines, increased levels of prostaglandins, the infiltration of cells from the bloodstream, and the generation of reactive oxygen (ROS) and nitrogen species (NOS) (Figure 1) [38-40].

Neuroinflammation is regulated by components of the immune system, and by pathogen recognition receptors (PRRs) [41]. Similarly, the entry of calcium into the cell through the activity of channels and hemichannels positively regulates neuroinflammation [42], which is a common consequence of epileptic seizures, and the pathogenesis of some types of acquired and genetic epilepsy [43]. 


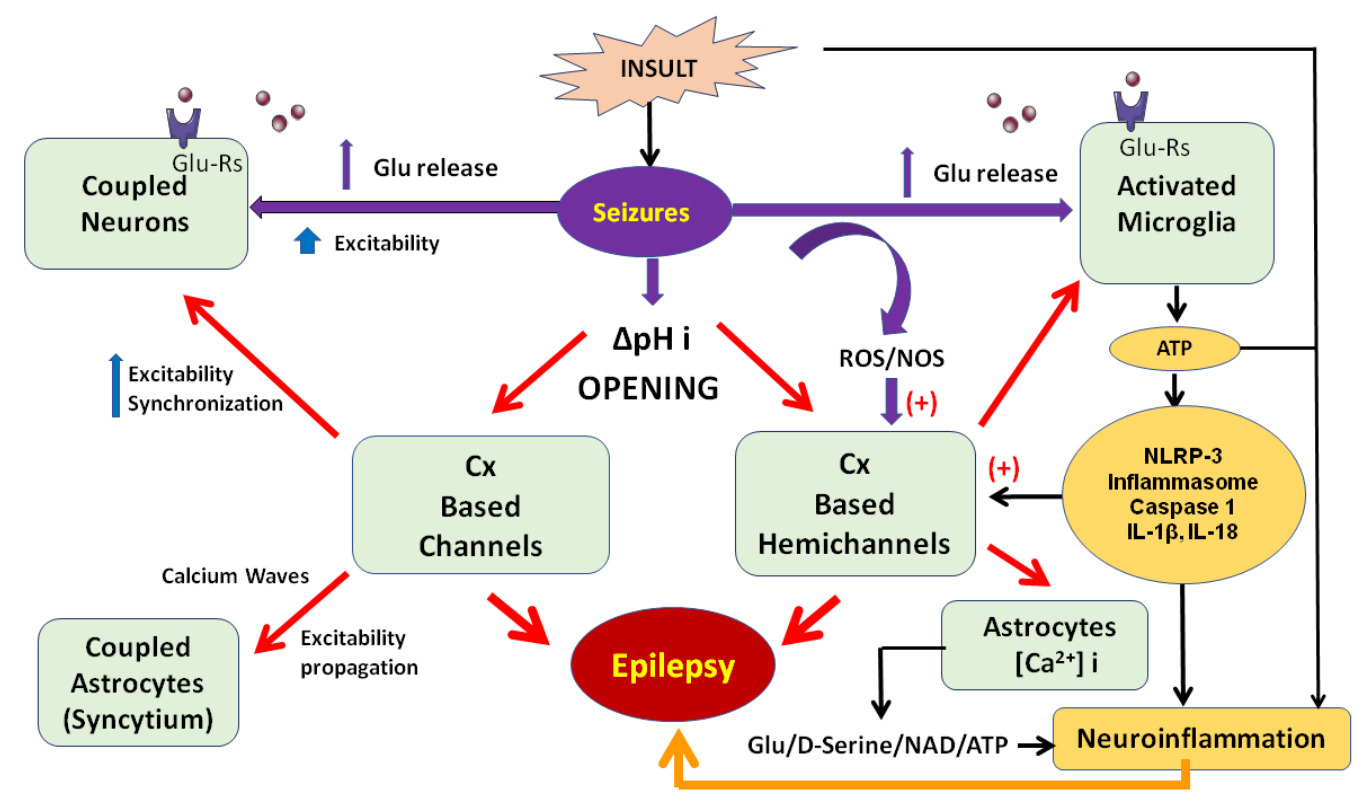

Figure 1. General representation of the connexins (Cxs)-based channels and hemichannels participation in seizures and epilepsy, through synergistic actions of neuroinflammation and hyper excitability and synchronization. Different types of insults can produce seizures that modify intracellular $\mathrm{pH}$, which opens hemichannels in glial cells (activated microglia and astrocytes), with the consequent calcium-dependent release of gliotransmitters (Glutamate Glu, D-serine, NAD and ATP) and proinflammatory molecules (NLRP-3 inflammasome: Caspase 1, IL-1 $\beta$, IL18) that lead to neuroinflammation and open Cxs-based hemichannels. This last action is also facilitated by reactive oxygen species (ROS) and reactive nitrogen species (NOS) produced during seizures. In the same way, astrocytes can reinforce seizures through the opening of Cxs-based channels that activate a calcium wave in an astroglial syncytium that propagates excitability. In neurons, the opening of channels increases abnormal high excitability and synchronization that reinforces the cycle of seizures generation.

The binding of pathogen-associated molecular patterns (PAMPs) or damage-associated molecular patterns (DAMPs) to PRRs causes the activation of signaling pathways that result in neuroinflammation [44]. Some DAMPS include ATP, interleukin (IL)-1 $\beta$, IL6, IL11, IL15, IL17, TNF $\alpha$, uric acid, and high-mobility protein group 1 (HMGB1) $[45,46]$. In this sense, Cxs plays an important role in the generation and maintenance of neuroinflammation, because hemichannels have little selectivity, and their opening is considered harmful since neurotoxic damage can be caused by the induced release of gliotransmitters, ATP, glutamate, and other molecules (Figure 1) [47].

Hemichannels formed by Cxs are activated by the presence of proinflammatory cytokines (TNF $\alpha$ and IL1 $\beta$ ) and ROS [48] through increases in the concentrations of intracellular $\mathrm{Ca}^{2+}$ and extracellular $\mathrm{K}^{+}$and ATP, as well as decreases in the extracellular concentration of $\mathrm{Ca}^{2+}$ and the redox potential $[49,50]$. Then, under stressful conditions, Cxs-based hemichannels amplify the damage and induce neuroinflammation [51]. However, once inflammation is established, positive feedback that promotes increased opening of Cxs-based hemichannels is produced [52]. The opening of Cxs-based channels and hemichannels due to inflammation begins a positive feedback cycle that, among other things, results in excessive ATP release [53].

It is recognized that inflammation is activated by two signals. Of these signals, one is mediated by the activation of PRRs through PAMPs or DAMPs that result in the induction of the NF- $\mathrm{KB}$ pathway, which promotes the expression of pro-IL- $1 \beta$, and genes associated with inflammatory proteins $[54,55]$. The second signal is attributed to ATP [56-58] and glutamate via N-methyl-D-aspartate (NMDA) receptors $[59,60]$. For example, it has been observed that, in astrocytes, the activation of exogenous ATP-induced inflammation triggers an increase in IL-1 $\beta$ production [61]. 
Under neurodegenerative conditions, neuroinflammation involves the primordial participation of CNS cells, including microglia, oligodendrocytes, and astrocytes [62,63]. Astrocytes were first described by Dieters in 1865, and named by von Lenhossék in 1895, they are currently known as the most abundant cell type in the CNS [64,65]. Astrocytes participate in a large number of functions, including those related to pro- and anti-inflammatory processes, that either contribute to inflammation [66-68] or respond to it [69], and in epilepsy [70]. The expression of Cx43, and in lower quantities Cx26 and $\mathrm{Cx30}$, of channels and hemichannels in astrocytes is relevant to neuroinflammatory processes because it allows both the exchange of small molecules [71], and gliotransmission [72-74].

Neuroinflammation induces the activation of two types of reactive astrocytes, called A1 and A2, as determined by transcriptome analysis. It has been suggested that the activation of A1 by NF- $\mathrm{kB}[75,76]$, but not the activation of $\mathrm{A} 2$ has reinforcing effects on inflammation. Additionally, reactive astrocytes increase the expression of genes responsible for the formation of synapses that can, nevertheless, lead to epilepsy [77]. Another relevant feature of astrocytes is their high degree of interconnection through Cxs-based channels, which create large functional syncytial networks, that are electrically and metabolically coupled, through which network $\mathrm{Ca}^{2+}$ waves can propagate excitability $[78,79]$.

Oligodendrocytes are small myelin-forming cells that are widely distributed in the CNS, and based on morphology, can be divided into four subtypes [80]. They mainly contribute to conduction inside neuronal circuits, but they also participate in metabolic supply and ion buffering [81,82]. Oligodendrocytes mainly express Cx29, Cx32, and Cx47; through these connections, they form channels with astrocytes and with themselves (heterotypic unions of $C \times 30$ and $C \times 32$, and of $C \times 43$ and $C \times 47$ ) $[7,83]$. These functional unions of $\mathrm{Cxs}$ even participate in the release of gliotransmitters, although it is not clear if oligodendrocytes have the necessary molecular machinery to fulfill this task [84]. It has also been suggested that oligodendrocytes may be associated with acquired neuroinflammation [78], but more robust information, as well as increased information on the involvement of oligodendrocytes in neuroinflammation, is needed.

Microglia are tissue-resident innate immune cells of the CNS that constitute approximately $5-10 \%$ of all CNS cells [85]. The resting state or non-activated state of microglia [86] may result from signals, such as transforming growth factor- $\beta$ (TGF $\beta$ ), an anti-inflammatory cytokine that is constitutively expressed in the CNS in the non-inflamed brain [87]. Microglia, particularly those that focus on debris clearing and the elimination of dead cells and synapses are essential in the maturation of neuronal circuits [88], the development of synaptic plasticity [89], and CNS homeostasis [90,91]. In the resting state, microglia exhibit their own Cxs profile, which involves the expression of Cx32 [92] and Cx36 [93,94]; however, Cx43 is not expressed by microglia [95-97].

Under neurological conditions such as epilepsy, microglia are rapidly activated, release proinflammatory cytokines, take on an amoeboid morphology, express a large number of surface receptors, and can detect DAMPs, which are recognized by PRRs [98-101], all of these can lead to neuronal hyperexcitability and neurodegeneration. Several studies have shown an increase in the expression of Cx32 [102], Cx36 [103], and Cx43 in microglia, which has been correlated with the development of chronic degenerative diseases. Additionally, it has been shown that, during the establishment of neurological damage, such as seizures and epilepsy, ATP is released mainly by the Cxs of astrocytes, and the pannexins of oligodendrocytes [104,105]. In vivo and in vitro studies have shown that the excessive release of ATP and glutamate is toxic to the CNS [104-106]; subsequently, ATP is recognized by P2x7 microglial receptors, and their activation causes potassium outflow, which is a critical event for the activation of the NLRP3 inflammasome. A central framework receptor, called nucleotide-binding oligomerization domain-like receptor family pyrin domain containing 3 (NLRP3) that initiates signaling, and three key protein organization-based proteins, results in the recruitment of procaspases and caspases (Figure 1) [107]. The assembly of the NLRP3 inflammasome results in the conversion of procaspase- 1 from its pro form to its active form, which then processes the cleavage of several substrates, such as pro-IL-1 $\beta$ and pro-IL-18, in the mature cytokines IL- $1 \beta$ and 
IL-18 [108]; this process can aggravate inflammation. In addition, numerous studies have implicated neuroinflammation as the cause, and result, of epilepsy $[109,110]$.

\section{Blockers of Connexins-Based Channels/Hemichannels as Anticonvulsive and Antiepileptic Therapeutic Targets in Different Models of Seizures and Epilepsy}

Metabolic, mechanical, or genetic insults, as well as an imbalance between $\gamma$-Aminobutyric Acid (GABA) and glutamate, can generate seizures through the excessive release of glutamate [111], and the overactivation of their receptors in neurons and astrocytes; this results in an increase in intercellular calcium concentrations in both types of cells [112-114]. However, the effect of this activation and association with Cxs-based channels and hemichannels can establish prolonged seizures and epilepsy through different paths in neurons and glial cells (Figure 1).

In neurons, it can drive hyperexcitability and synchronicity as a consequence of intense neuronal firing between pyramidal cells of the hippocampus that is sustained by the uncontrolled opening of axo-axonal Cxs-based channels, induced by $\mathrm{pH}$ changes (alkalinization) [31,115-117], or be as observed in dendritic Cxs-based channels with strong olivary coupling, after the activation of NMDA receptors in inferior olive neurons $[118,119]$. Additionally, these observations support the chemical modulation of Cxs-based channels and hemichannels by neurotransmitters, such as glutamate or even serotonin (5-HT) [19]. The pathological alkaline-acidosis environment generated during and after seizures facilitate the conductance of Cxs-based channels that strengthens neuronal coupling in networks, which induces increased synchronization and excitability (Figure 1) [120-124].

These facts can be assessed by in vitro and in vivo pharmacological experiments, in which the blockade of Cxs-based channels or hemichannels, has been shown to have anti-convulsive effects (Table 1). These studies used non-specific blockers such as carbenoxolone, quinine, and mefloquine, and the combination of these drugs with classic anti-convulsants [125-133]; carbenoxolone blocks Cxs indistinctly via the phosphorylation or internalization of Cxs subunits [134-137], quinine blocks not only Cx36- and Cx50-based channels, but also ion channels associated with the electric membrane properties of neurons [134-141], and mefloquine has effects on different neurotransmitter systems, acting as a GABA A antagonist or inhibiting 5-HT3 receptors [142]; it induces short action potentials and has effects on L-type calcium channels [143], in some cases increasing spontaneous excitatory currents [144].

However, studies in which more effective drugs, including mimetic peptides such as Gap 26 (sequence: VCYDKSFPISHVR) and Gap 27 (sequence: SRPTEKTIFI), were used to block Cxs-based channels or hemichannels showed similar results [145-147]; in this respect, Gap 27, a specific peptide to the extracellular loop domain of Cx43, Cx40, and Cx37, decreased recurrent epileptiform activity in hippocampal slices [146], and prevented neuronal death caused by seizures induced by the GABA-A receptor antagonist bicuculline [147].

The pathological cycle of hyperexcitability and synchronization can trigger epileptogenesis, and Cxs-based channels and hemichannels play an important role in this process, since some studies have shown their participation in fast ripples, a high frequency oscillation that is considered an electrophysiological marker of epileptogenicity $[148,149]$. Several studies have demonstrated that fast ripples are decreased by blockers of Cxs-based channels and hemichannels in the hippocampus of animals with pilocarpine-induced epilepsy [150,151], as well as in vitro and in silico [152]. These facts indicate their importance and how hypersynchronization and excitability of neurons synergistically with neuroinflammation maintain pathological conditions in networks that address cerebral damage and cell loss, which favor epileptogenesis.

In glial cells (astrocytes and microglia), after the activation of glutamate receptors (NMDA, AMPA and metabotropic glutamate receptors), gliotransmitters such as ATP, glutamate, Nicotinamide Adenine Dinucleotide (NAD), and D-serine are released through Cxs-based hemichannels, which sustain an excitatory extracellular environment through the activation of extrasynaptic NMDA receptors in neurons of the hippocampus (CA1), and together with astrocytic calcium waves in networks, propagate neuronal 
activity, increasing the excitability and synchronicity of surrounding neurons (Figure 1), as observed in various pharmacologic in vitro studies [146,153-156]. Additionally, as described previously, the release of gliotransmitters can modulate the inflammatory response, activate immunological cells, and synergistically trigger irreversible neuronal damage [157]. Moreover, Cxs-based hemichannels can support epileptic activity by supplying glucose to epileptic neuronal networks [158].

There are specific pharmacological blockers of Cxs-based hemichannels, such as peptide 5 (with a short incubation time or at a low concentration), Gap 19, and $\mathrm{La}^{3+}$, that have been used in a few studies to support the principal role of hemichannels in seizures, and to demonstrate their anti-convulsive effects in in vitro models [159,160], and in some animal models of seizures [160]. In this last study, the suppression of seizures was associated with a decrease in D-serine concentration. Despite the importance of Cxs-based hemichannels in seizures and epilepsy (Table 1), there have been few pharmacological studies that have demonstrated the use of these drugs as a new therapeutic strategy against seizures and epilepsy. Accordingly, it is necessary to continue researching this topic experimentally, to further understand their potential as anti-convulsive and anti-epileptic treatments. 
Table 1. Anticonvulsive effects of principal blockers of Cxs-based hemichannels and channels in different in vitro and in vivo models of seizures and epilepsy.

\begin{tabular}{|c|c|c|c|c|}
\hline $\begin{array}{c}\text { Blocker(s) of Cxs-Based Hemichannels } \\
\text { or Channels }\end{array}$ & Seizure or Epilepsy Model & Technique/Brain Region & Main Results & Citation \\
\hline $\begin{array}{l}\text { Carbenoxolone }(10 \mu \mathrm{M}) \text { and quinine ( } 35 \\
\mu \mathrm{M}) \text { administered through a piece of } \\
\text { filter paper covering the cortical surface }\end{array}$ & $\begin{array}{l}\text { In vivo: local application of crystalline } \\
4 \text {-AP on the surface of the cortex }\end{array}$ & $\begin{array}{l}\text { Electrocorticography }(\mathrm{ECoG}) \text { in the brains of } \\
\text { adult Wistar rats (male and female, 30-40 } \\
\text { days old, 200-250 g) }\end{array}$ & $\begin{array}{l}\text { Anticonvulsive effect of carbenoxolone } \\
\text { (reduced the generation of seizure } \\
\text { discharges); quinine decreased summated } \\
\text { ictal activity and the amplitudes of seizure } \\
\text { discharges }\end{array}$ & [125] \\
\hline $\begin{array}{l}\text { Carbenoxolone }(150 \mathrm{mM}) \text { and } \\
\text { meclofenamic acid }(50 \mathrm{mM}) \text { administered } \\
\text { through a cannula implanted in the right } \\
\text { motor cortex }\end{array}$ & $\begin{array}{l}\text { In vivo: a model of refractory focal } \\
\text { cortical epilepsy induced with tetanus } \\
\text { toxin }(50 \mathrm{ng} / 0.5 \mu \mathrm{L}, \mathrm{pH} 7.5) \text { in } 2 \% \text { bovine } \\
\text { serum albumin }\end{array}$ & $\begin{array}{l}\text { Intracranial electroencephalography (iEEG) } \\
\text { in the right motor cortex of adult } \\
\text { Sprague-Dawley rats }(240-320 \mathrm{~g})\end{array}$ & Reduced the percentage of seizure time & [126] \\
\hline $\begin{array}{l}\text { Quinine }(200,400 \text { or } 1000 \mathrm{nmol}) \\
\text { administered through a cannula } \\
\text { implanted in the ventricle of the brain }\end{array}$ & $\begin{array}{l}\text { In vivo: a model of epilepsy induced by } \\
300 \text { IU of crystallized penicillin }\end{array}$ & $\begin{array}{c}\text { Epidural EEG in adult Wistar rats (male, } 4 \\
\text { months) }\end{array}$ & $\begin{array}{l}\text { Decreased the amplitude and frequency of } \\
\text { epileptiform spikes and attenuated } \\
\text { convulsive behavior }\end{array}$ & [127] \\
\hline $\begin{array}{l}\text { Carbenoxolone injection }(50 \mathrm{nmol}) \\
\text { administered through a cannula } \\
\text { implanted in the entorhinal cortex }\end{array}$ & $\begin{array}{c}\text { In vivo: a model of seizures induced by } \\
\text { 4-aminopyridine ( } 10 \text { nmol) administered } \\
\text { through a cannula implanted in the } \\
\text { entorhinal cortex }\end{array}$ & $\begin{array}{l}\text { Epidural EEG and iEEG in the entorhinal } \\
\text { cortex of adult Wistar rats (male, } 250-350 \mathrm{~g} \text { ) }\end{array}$ & $\begin{array}{l}\text { Decreased the amplitude and frequency of } \\
\text { epileptiform discharges and the number and } \\
\text { duration of epileptiform trains }\end{array}$ & [128] \\
\hline $\begin{array}{l}\text { Carbenoxolone, Gap } 27 \text { (mimetic amino } \\
\text { acid residues 201-211, SRPTEKTIFII) and } \\
\text { SLS (amino acid residues 180-195, } \\
\text { SLSAVYTCKRDPCPHQ) peptides }\end{array}$ & $\begin{array}{c}\text { In vitro: epileptiform activity induced in } \\
\text { organotypic hippocampal slice cultures } \\
\text { by stimulation }\end{array}$ & $\begin{array}{c}\text { Extracellular recordings from the CA1 and } \\
\text { CA3 regions of hippocampal slices from } \\
\text { 7-day-old Wistar rats }\end{array}$ & $\begin{array}{l}\text { Carbenoxolone inhibited both spontaneous } \\
\text { and evoked seizure-like events; the Cx43 } \\
\text { mimetic peptides selectively attenuated } \\
\text { spontaneous recurrent epileptiform activity } \\
\text { after prolonged }(10 \mathrm{~h}) \text { treatment }\end{array}$ & [146] \\
\hline $\begin{array}{l}\text { Quinine injection ( } 35 \mathrm{pmol} \text { ) administered } \\
\text { through a cannula implanted in the } \\
\text { entorhinal cortex }\end{array}$ & $\begin{array}{c}\text { In vivo: a model of seizures induced by } \\
\text { 4-aminopyridine ( } 10 \text { nmol) administered } \\
\text { through a cannula implanted in the } \\
\text { entorhinal cortex }\end{array}$ & $\begin{array}{l}\text { Epidural EEG and iEEG in the entorhinal } \\
\text { cortex of adult Wistar rats (male, } 250-350 \mathrm{~g} \text { ) }\end{array}$ & $\begin{array}{l}\text { Decreased the amplitude and frequency of } \\
\text { discharge trains and blocked seizure } \\
\text { behavior in five of six rats }\end{array}$ & [129] \\
\hline $\begin{array}{l}\text { Cx43 mimetic peptide (5 and } 50 \mu \mathrm{M} \text {, } \\
\text { sufficient to block hemichannels, } \\
\text { VDCFLSRPTEKT, extracellular loop two } \\
\text { of } \mathrm{C} \times 43)\end{array}$ & $\begin{array}{l}\text { In vitro: a model of epileptiform injury } \\
\text { induced by bicuculline methochloride } \\
\text { (BMC) ( } 48 \text { h exposure to } 100 \mu \mathrm{M}) \text { in } \\
\text { hippocampal slices cultures from 6- to } \\
\text { 8-day-old Wistar rats }\end{array}$ & $\begin{array}{l}\text { Measurement of cell death after } \\
\text { epileptiform activity (fluorescence signal) } \\
\text { and immunohistochemistry for } \\
\text { microtubule-associated protein (MAP2) }\end{array}$ & $\begin{array}{c}\text { Exerted a protective effect in the CA1 region } \\
\text { during the recovery period ( } 24 \mathrm{~h} \text { after BMC } \\
\text { treatment) }\end{array}$ & [147] \\
\hline $\begin{array}{c}\text { Carbenoxolone }(20 \mathrm{mg} / \mathrm{kg} \text {, i.p.) once } \\
\text { a day for } 14 \text { days }\end{array}$ & $\begin{array}{l}\text { In vivo: a model of posttraumatic } \\
\text { epilepsy induced by ferric ions } \\
\text { (microinjection of } 10 \mu \mathrm{L} \text { of } 0.1 \mathrm{M} \mathrm{FeCl}_{3} \\
\text { solution into the sensorimotor area) }\end{array}$ & $\begin{array}{c}\text { Evaluation of convulsive behavior } \\
\text { according to the Racine scale in adult male } \\
\text { Sprague-Dawley rats aged 6-8 weeks and } \\
\text { weighing } 220-250 \mathrm{~g}\end{array}$ & $\begin{array}{c}\text { Ameliorated convulsive behavior score in } \\
\text { rats }\end{array}$ & [130] \\
\hline
\end{tabular}


Table 1. Cont

\begin{tabular}{|c|c|c|c|c|}
\hline $\begin{array}{c}\text { Blocker(s) of Cxs-Based Hemichannels } \\
\text { or Channels }\end{array}$ & Seizure or Epilepsy Model & Technique/Brain Region & Main Results & Citation \\
\hline $\begin{array}{l}\text { Carbenoxolone }(50 \mathrm{nmol}) \text { and quinine }(35 \\
\text { pmol) administered through a guide } \\
\text { cannula in the entorhinal cortex }(0.2 \\
\mu \mathrm{L} / \mathrm{min} \text { for } 5 \mathrm{~min})\end{array}$ & $\begin{array}{c}\text { In vivo: a pilocarpine-induced model of } \\
\text { temporal lobe epilepsy }(1.2 \mathrm{mg} / \mu \mathrm{L} \\
\text { pilocarpine hydrochloride in a total } \\
\text { volume of } 2 \mu \mathrm{L} \text {, intracerebroventricular } \\
\text { (i.c.v.) }\end{array}$ & $\begin{array}{l}\text { iEEG in the hippocampus of epileptic adult } \\
\text { Wistar rats (male, 190-200 g) }\end{array}$ & $\begin{array}{l}\text { Decreased the number of Fast Ripples (FR) } \\
\text { events and oscillation cycles per FR event }\end{array}$ & [150] \\
\hline \multirow[t]{2}{*}{ Carbenoxolone $(0.2 \mathrm{mM})$} & In vitro: Neocortical slices & $\begin{array}{l}\text { Neocortical slices from epileptic patients } \\
\text { (temporal and occipital regions) }\end{array}$ & Strongly decreased the incidence of FR events & \multirow[t]{2}{*}{ [152] } \\
\hline & $\begin{array}{l}\text { In silico: a small network of } 256 \\
\text { multicompartment cells }\end{array}$ & $\begin{array}{c}\text { Simulated networks containing only } \\
\text { pyramidal cells, coupled only by axonal gap } \\
\text { junctions, and without chemical synapses or } \\
\text { interneurons }\end{array}$ & $\begin{array}{l}\text { The network produced FR events via } \\
\text { a cluster of axonal Cx-based channels (gap } \\
\text { junctions) }\end{array}$ & \\
\hline $\begin{array}{c}\text { Carbenoxolone }(40 \mathrm{mg} / \mathrm{kg} \text {, i.p.) and } \\
\text { carbenoxolone }+ \text { valproic acid (300 } \\
\mathrm{mg} / \mathrm{kg} \text {, i.p.) }\end{array}$ & $\begin{array}{l}\text { In vivo: a kindling model of epilepsy } \\
\text { induced by pentylenetetrazole ( } 35 \mathrm{mg} / \mathrm{kg} \text {, } \\
\text { i.p.) }\end{array}$ & $\begin{array}{c}\text { Epidural EEG in Wistar rats (female, 12-15 } \\
\text { weeks old, } 200 \pm 50 \mathrm{~g} \text { ) }\end{array}$ & $\begin{array}{c}\text { Carbenoxolone prevented generalized } \\
\text { seizures and reduced seizure stage, seizure } \\
\text { duration and spike frequency; no significant } \\
\text { difference between carbenoxolone + valproic } \\
\text { acid and valproic acid }\end{array}$ & [131] \\
\hline $\begin{array}{l}\text { Carbenoxolone }(50 \mathrm{mg} / \mathrm{kg} \text {, i.p., for } 3 \text { days) } \\
\text { and quinine }(50 \mathrm{mg} / \mathrm{kg} \text {, i.p. for } 3 \text { days })\end{array}$ & $\begin{array}{l}\text { In vivo: a lithium/pilocarpine-induced } \\
\text { Status epilepticus (SE) model (i.p. injection } \\
\text { of } 50 \mathrm{mg} / \mathrm{kg} \text { pilocarpine } 18-20 \mathrm{~h} \text { after the } \\
\text { i.p. injection of } 127 \mathrm{mg} / \mathrm{kg} \text { lithium } \\
\text { chloride) }\end{array}$ & $\begin{array}{l}\text { iEEG in the hippocampus of adult } \\
\text { Sprague-Dawley rats (male) }\end{array}$ & $\begin{array}{l}\text { Reduced the spectral power of FR events } 10 \\
\text { min after SE }\end{array}$ & [151] \\
\hline $\begin{array}{l}\text { Coadministration of valproate (VPA), } \\
\text { phenytoin (PHT), or carbamazepine } \\
\text { (CBZ) at subtherapeutic doses (i.p.) with } \\
\text { carbenoxolone }(60 \mathrm{mg} / \mathrm{kg}, \text { i.p., } 5 \mathrm{~mL} / \mathrm{kg}) \\
\text { or quinine }(40 \mathrm{mg} / \mathrm{kg} \text {, i.p., } 5 \mathrm{~mL} / \mathrm{kg})\end{array}$ & $\begin{array}{l}\text { In vivo: maximal electroshock } \\
\text { (MES)-induced (frequency of } 60 \mathrm{~Hz} \\
\text { pulse width of } 0.6 \mathrm{~ms} \text {, shock duration of } \\
0.6 \mathrm{~s} \text {, and a current of } 90 \mathrm{~mA} \text { ) and } \\
\text { pentylenetetrazole (PTZ)-induced ( } 70 \\
\mathrm{mg} / \mathrm{kg} \text {, i.p.) models of seizures }\end{array}$ & $\begin{array}{l}\text { EEG and power spectral analysis in Wistar } \\
\text { rats (male, 270-300 g) }\end{array}$ & $\begin{array}{l}\text { Quinine increased the anticonvulsant activity } \\
\text { of VPA, PHT and CBZ to generalized } \\
\text { tonic-clonic seizures in the MES-induced } \\
\text { model and the anticonvulsant activity of CBZ } \\
\text { only to generalized tonic-clonic seizures in } \\
\text { the PTZ-induced model }\end{array}$ & [132] \\
\hline
\end{tabular}


Table 1. Cont.

\begin{tabular}{|c|c|c|c|c|}
\hline $\begin{array}{l}\text { TAT-Gap } 19 \text { ( } 200 \mathrm{mM} \text { for in vitro } \\
\text { experiments; } 12 \mathrm{mM} \text { intrahippocampal } \\
\text { and } 1 \mathrm{mM} \text { in a total volume of } 1 \mu \mathrm{L} \text { i.c.v. } \\
\text { for in vivo experiments); } \\
\text { TAT-Gap19 ( } 25 \mathrm{or} 50 \mathrm{mg} / \mathrm{kg} \text { i.p., electrical } \\
\text { stimulation for in vivo experiments) }\end{array}$ & $\begin{array}{l}\text { In vitro: pilocarpine }(15 \mu \mathrm{M}) \\
\text { administration in acute brain slices; } \\
\text { In vivo: pilocarpine model in mice and } \\
\text { rats }(12 \mathrm{mM} \text {, intra hippocampal) } \\
\text { Limbic psychomotor seizures by corneal } \\
\text { stimulation }\end{array}$ & $\begin{array}{l}\text { In vitro: ethidium bromide uptake } \\
\text { experiments in acute brain slices from Glial } \\
\text { Fibrillary Acidic Protein-enhanced Green } \\
\text { Fluorescent Protein (GFAP-eGFP) transgenic } \\
\text { mice (both genders, } 2 \text { months old); } \\
\text { In vivo: video-EcoG analysis (seizure } \\
\text { duration) or modified Racine's scale } \\
\text { evaluation (to score kindling-induced } \\
\text { behavioral changes) in NMRI mice (male, } \\
\text { 20-30 g) and, video-EcoG and Racine scale } \\
\text { evaluation of convulsive behavior in Wistar } \\
\text { rats (male, } 250-300 \mathrm{~g} \text { ) }\end{array}$ & $\begin{array}{l}\text { In vitro: dye uptake experiments } \\
\text { demonstrated that astroglial Cx43 } \\
\text { hemichannels open in response to } \\
\text { pilocarpine, and this was inhibited by } \\
\text { TAT-Gap19. } \\
\text { In vivo: TAT-Gap19 suppressed seizures and } \\
\text { decreased D-serine concentrations; these } \\
\text { effects were reversed by exogenous D-serine } \\
\text { administration, and a similar effect was } \\
\text { observed for the electrical stimulation model }\end{array}$ & [160] \\
\hline $\begin{array}{l}\text { In vitro experiments: Carbenoxolone }(200 \\
\mathrm{mM}) \text { quinine }(100 \mathrm{mM}) \text { and } \mathrm{La}\left(\mathrm{NO}_{3}\right)_{3}(\mathrm{a} \\
\text { blocker of Cx-based hemichannels) } \\
\text { In vivo experiments: carbenoxolone }(100 \\
\mathrm{mg} / \mathrm{kg}) \text { and quinine }(40 \mathrm{mg} / \mathrm{kg})\end{array}$ & $\begin{array}{l}\text { In vitro: low-Mg2+-induced epilepsy } \\
\text { model } \\
\text { In vivo: Wistar Albino Glaxo/ Rijswijk } \\
\text { (WAG/Rij) rat model of absence epilepsy }\end{array}$ & $\begin{array}{l}\text { Field potential recordings, evaluation of } \\
\text { seizure-like events (SLEs) in } \\
\text { hippocampal-entorhinal slices from Wistar } \\
\text { rats (11-14 days old); epidural EEG (frontal } \\
\text { and parietal cortex) in WAG/Rij rats (female, } \\
\text { 11-12 months old, 195-210 g); recordings of } \\
\text { bilaterally synchronous spike-wave } \\
\text { discharges (SWDs) }\end{array}$ & $\begin{array}{l}\text { Carbenoxolone prevented the occurrence of } \\
\text { SLEs and aggravated seizures in } \\
\text { non-convulsive absence epilepsy; quinine } \\
\text { did not prevent SLEs but increased the } \\
\text { number and total time of SWDs and } \\
\text { decreased the length of the interictal } \\
\text { intervals; } \text { La }^{3+} \text { completely abolished SLEs }\end{array}$ & [159] \\
\hline
\end{tabular}




\section{Conclusions}

There is evidence regarding the relationship between Cxs-based channels and hemichannels on seizures and epilepsy in different models, in which the uncontrolled opening of these channels by $\mathrm{pH}$ changes as a consequence of intense neuronal firing sustains inflammation, hyperexcitability, and synchronicity that maintain this pathological condition. The use of some blockers of Cxs-based channels and hemichannels may be therapeutic agents for the treatment of seizures and epilepsy.

Author Contributions: Conceptualization, L.M.-C.; investigation, L.M.-C., J.C.S.-S., J.O.-I.; writing-original draft preparation, L.M.-C., J.C.S.-S., J.O.-I., A.M.-V.; writing-review and editing, L.M.-C., A.M.-V.

Funding: This research was funded by CONACYT-BASIC SCIENCE, grant number 250930.

Conflicts of Interest: The authors declare no conflict of interest. The funders had no role in the design of the study; in the collection, analyses, or interpretation of data; in the writing of the manuscript, or in the decision to publish the results.

\section{References}

1. Flores, C.E.; Nannapaneni, S.; Davidson, K.G.; Yasumura, T.; Bennett, M.V.; Rash, J.E.; Pereda, A.E. Trafficking of gap junction channels at a vertebrate electrical synapse in vivo. Proc. Natl. Acad. Sci. USA 2012, 109, E573-E582. [CrossRef] [PubMed]

2. Pereda, A.E.; Curti, S.; Hoge, G.; Cachope, R.; Flores, C.E.; Rash, J.E. Gap junction-mediated electrical transmission: Regulatory mechanisms and plasticity. Biochim. Biophys. Acta 2013, 1828, 134-146. [CrossRef] [PubMed]

3. Zancan, M.; Malysz, T.; Moura, D.J.; Morás, A.M.; Steffens, L.; Rasia-Filho, A.A. Gap junctions and expression of Cx36, Cx43 and Cx45 in the posterodorsal medial amygdala of adult rats. Histol. Histopathol. 2019, 9, 18160.

4. Condorelli, D.F.; Mudò, G.; Trovato-Salinaro, A.; Mirone, M.B.; Amato, G.; Belluardo, N. Connexin-30 mRNA is up-regulated in astrocytes and expressed in apoptotic neuronal cells of rat brain following kainate-induced seizures. Mol. Cell. Neurosci. 2002, 21, 94-113. [CrossRef] [PubMed]

5. Ghézali, G.; Vasile, F.; Curry, N.; Fantham, M.; Cheung, G.; Ezan, P.; Cohen-Salmon, M.; Kaminski, C.; Rouach, N. Neuronal Activity Drives Astroglial Connexin 30 in Perisynaptic Processes and Shapes Its Functions. Cereb. Cortex 2019. [CrossRef]

6. Dermietzel, R.; Farooq, M.; Kessler, J.A.; Althaus, H.; Hertzberg, E.L.; Spray, D.C. Oligodendrocytes express gap junction proteins connexin32 and connexin45. Glia 1997, 20, 101-114. [CrossRef]

7. Nagy, J.I.; Ionescu, A.V.; Lynn, B.D.; Rash, J.E. Connexin29 and connexin32 at oligodendrocyte and astrocyte gap junctions and in myelin of the mouse central nervous system. J. Comp. Neurol. 2003, 464, 356-370. [CrossRef]

8. Dobrenis, K.; Chang, H.Y.; Pina-Benabou, M.H.; Woodroffe, A.; Lee, S.C.; Rozental, R.; Spray, D.C.; Scemes, E. Human and mouse microglia express connexin36, and functional gap junctions are formed between rodent microglia and neurons. J. Neurosci. Res. 2005, 82, 306-315. [CrossRef]

9. Gajardo-Gómez, R.; Labra, V.C.; Orellana, J.A. Connexins and Pannexins: New Insights into Microglial Functions and Dysfunctions. Front. Mol. Neurosci. 2016, 9, 86. [CrossRef]

10. Shaikh, S.B.; Uy, B.; Perera, A.; Nicholson, L.F. AGEs-RAGE mediated up-regulation of connexin 43 in activated human microglial CHME-5 cells. Neurochem. Int. 2012, 60, 640-651. [CrossRef]

11. Veenstra, R.D.; Wang, H.Z.; Beyer, E.C.; Brink, P.R. Selective dye and ionic permeability of gap junction channels formed by connexin 45. Circ. Res 1994, 75, 483-490. [CrossRef]

12. Bukauskas, F.F. Neurons and $\beta$-cells of the pancreas express connexin36, forming gap junction channels that exhibit strong cationic selectivity. J. Membr. Biol. 2012, 245, 243-253. [CrossRef]

13. Abudara, V.; Retamal, M.A.; Del Rio, R.; Orellana, J.A. Synaptic Functions of Hemichannels and Pannexons: A Double-Edged Sword. Front. Mol. Neurosci. 2018, 11, 435. [CrossRef]

14. Spray, D.C.; White, R.L.; Mazet, F.; Bennett, M.V. Regulation of gap junctional conductance. Am. J. Phys. 1985, 248, H753-H764. [CrossRef]

15. Ek Vitorín, J.F.; Pontifex, T.K.; Burt, J.M. Determinants of Cx43 Channel Gating and Permeation: The Amino Terminus. Biophys. J. 2016, 110, 127-140. [CrossRef] 
16. Perez-Velazquez, J.L.; Valiante, T.A.; Carlen, P.L. Modulation of gap junctional mechanisms during calcium-free induced field burst activity: A possible role for electrotonic coupling in epileptogenesis. J. Neurosci. 1994, 14, 4308-4317. [CrossRef]

17. González-Nieto, D.; Gómez-Hernández,J.M.; Larrosa, B.; Gutiérrez, C.; Muñoz, M.D.; Fasciani, I.; O’Brien, J.O.; Zappalà, A.; Cicirata, F.; Barrio, L.C. Regulation of neuronal connexin-36 channels by pH. Proc. Natl. Acad. Sci. USA 2008, 105, 17169-17174. [CrossRef]

18. Rimkute, L.; Kraujalis, T.; Snipas, M.; Palacios-Prado, N.; Jotautis, V.; Skeberdis, V.A.; Bukauskas, F.F. Modulation of Connexin-36 Gap Junction Channels by Intracellular $\mathrm{pH}$ and Magnesium Ions. Front. Physiol. 2018, 9, 362. [CrossRef]

19. Szabo, T.M.; Caplan, J.S.; Zoran, M.J. Serotonin regulates electrical coupling via modulation of extrajunctional conductance: H-current. Brain Res. 2010, 1349, 21-31. [CrossRef]

20. Vivar, C.; Traub, R.D.; Gutiérrez, R. Mixed electrical-chemical transmission between hippocampal mossy fibers and pyramidal cells. Eur. J. Neurosci. 2012, 35, 76-82. [CrossRef]

21. Fasciani, I.; Pluta, P.; González-Nieto, D.; Martínez-Montero, P.; Molano, J.; Paíno, C.L.; Millet, O.; Barrio, L.C. Directional coupling of oligodendrocyte connexin-47 and astrocyte connexin-43 gap junctions. Glia 2018, 66, 2340-2352. [CrossRef]

22. Bargiello, T.A.; Oh, S.; Tang, Q.; Bargiello, N.K.; Dowd, T.L.; Kwon, T. Gating of Connexin Channels by transjunctional-voltage: Conformations and models of open and closed states. Biochim. Biophys. Acta Biomembr. 2018, 1860, 22-39. [CrossRef]

23. Teubner, B.; Degen, J.; Söhl, G.; Guldenagel, M.; Bukauskas, F.E.; Trexler, E.B.; Verselis, V.K.; De Zeeuw, C.I.; Lee, C.G.; Kozak, C.A.; et al. Functional expression of the murine connexin 36 gene coding for a neuron-specific gap junctional protein. J. Membr. Biol. 2000, 176, 249-262. [CrossRef]

24. Srinivas, M.; Rozental, R.; Kojima, T.; Dermietzel, R.; Mehler, M.; Condorelli, D.F.; Kessler, J.A.; Spray, D.C. Functional properties of channels formed by the neuronal gap junction protein connexin 36. J. Neurosci. 1999, 19, 9848-9855. [CrossRef]

25. Zhong, G.; Akoum, N.; Appadurai, D.A.; Hayrapetyan, V.; Ahmed, O.; Martinez, A.D.; Beyer, E.C.; Moreno, A.P. Mono-Heteromeric Configurations of Gap Junction Channels Formed by Connexin43 and Connexin45 Reduce Unitary Conductance and Determine both Voltage Gating and Metabolic Flux Asymmetry. Front. Physiol. 2017, 8, 346. [CrossRef]

26. Fukuda, T.; Kosaka, T. Gap junctions linking the dendritic network of GABAergic interneurons in the hippocampus. J. Neurosci. 2000, 20, 1519-1528. [CrossRef]

27. Baude, A.; Bleasdale, C.; Dalezios, Y.; Somogyi, P.; Klausberger, T. Immunoreactivity for the GABAA receptor $\alpha 1$ subunit, somatostatin and connexin36 distinguishes axoaxonic, basket, and bistratified interneurons of the rat hippocampus. Cereb. Cortex 2007, 17, 2094-2107. [CrossRef]

28. Zsiros, V.; Maccaferri, G. Noradrenergic modulation of electrical coupling in GABAergic networks of the hippocampus. J. Neurosci. 2008, 28, 1804-1815. [CrossRef]

29. Gibson, J.R.; Beierlein, M.; Connors, B.W. Functional properties of electrical synapses between inhibitory interneurons of neocortical layer 4. J. Neurophysiol. 2005, 93, 467-480. [CrossRef]

30. Mancilla, J.G.; Lewis, T.J.; Pinto, D.J.; Rinzel, J.; Connors, B.W. Synchronization of electrically coupled pairs of inhibitory interneurons in neocortex. J. Neurosci. 2007, 27, 2058-2073. [CrossRef]

31. Traub, R.D.; Whittington, M.A.; Buhl, E.H.; LeBeau, F.E.; Bibbig, A.; Boyd, S.; Cross, H.; Baldeweg, T. A possible role for gap junctions in generation of very fast EEG oscillations preceding the onset of, and perhaps initiating, seizures. Epilepsia 2001, 42, 153-170.

32. Nagy, J.I. Evidence for connexin36 localization at hippocampal mossy fiber terminals suggesting mixed chemical/electrical transmission by granule cells. Brain Res. 2012, 1487, 107-122. [CrossRef]

33. Hamzei-Sichani, F.; Davidson, K.G.V.; Yasumura, T.; Janssen, W.G.M.; Wearne, S.L.; Hof, P.R.; Traub, R.D.; Gutiérrez, R.; Ottersen, O.P.; Rash, J.E. Mixed electrical-chemical synapses in adult rat hippocampus are primarily glutamatergic and coupled by connexin-36. Front. Neuroanat. 2012, 6, 13. [CrossRef]

34. Barrientos, R.M.; Kitt, M.M.; Watkins, L.R.; Maier, S.F. Neuroinflammation in the normal aging hippocampus. Neuroscience 2015, 309, 84-99. [CrossRef]

35. Frank, M.G.; Weber, M.D.; Watkins, L.R.; Maier, S.F. Stress sounds the alarmin: The role of the danger-associated molecular pattern HMGB1 in stress-induced neuroinflammatory priming. Brain Behav. Immun. 2015, 48, 1-7. [CrossRef] 
36. Sofroniew, M.V. Astrocyte barriers to neurotoxic inflammation. Nat. Rev. Neurosci. 2015, 16, $249-263$. [CrossRef]

37. Kempuraj, D.; Thangavel, R.; Natteru, PA.; Selvakumar, GP.; Saeed, D.; Zahoor, H.; Zaheer, S.; Iyer, S.S.; Zaheer, A. Neuroinflammation Induces Neurodegeneration. J. Neurol. Neurosurg. Spine 2016, 1, 1003.

38. Reddy, D.S.; Kuruba, R. Experimental Models of Status Epilepticus and Neuronal Injury for Evaluation of Therapeutic Interventions. Int. J. Mol. Sci. 2013, 14, 18284-18318. [CrossRef]

39. Ransohoff, R.M.; Schafer, D.; Vincent, A.; Blachère, N.E.; Bar-Or, A. Neuroinflammation: Ways in Which the Immune System Affects the Brain. Neurotherapeutics 2015, 12, 896-909. [CrossRef]

40. Shabab, T.; Khanabdali, R.; Moghadamtousi, S.Z.; Kadir, H.A.; Mohan, G. Neuroinflammation pathways: A general review. Int. J. Neurosci. 2017, 127, 624-633. [CrossRef]

41. Hagberg, H.; Mallard, C.; Ferriero, D.M.; Vannucci, S.J.; Levison, S.W.; Vexler, Z.S.; Gressens, P. The role of inflammation in perinatal brain injury. Nat. Rev. Neurol. 2015, 11, 192-208. [CrossRef] [PubMed]

42. Shao, B.Z.; Xu, Z.Q.; Han, B.Z.; Su, D.F.; Liu, C. NLRP3 inflammasome and its inhibitors: A review. Front. Pharmacol. 2015, 6, 262. [CrossRef] [PubMed]

43. Vezzani, A.; Balosso, S.; Ravizza, T. Neuroinflammatory pathways as treatment targets and biomarkers in epilepsy. Nat. Rev. Neurol. 2019, 15, 459-472. [CrossRef] [PubMed]

44. Liu, J.; Buisman-Pijlman, F.; Hutchinson, M.R. Toll-like receptor 4: Innate immune regulator of neuroimmune and neuroendocrine interactions in stress and major depressive disorder. Front. Neurosci. 2014, 8, 309. [CrossRef]

45. Jensen, C.J.; Massie, A.; De Keyser, J. Immune players in the CNS: The astrocyte. J. Neuroimmune Pharmacol. 2013, 8, 824-839. [CrossRef]

46. Walker, A.K.; Kavelaars, A.; Heijnen, C.J.; Dantzer, R. Neuroinflammation and comorbidity of pain and depression. Pharmacol. Rev. 2014, 66, 80-101. [CrossRef] [PubMed]

47. Montero, T.D.; Orellana, J.A. Hemichannels: New pathways for gliotransmitter release. Neuroscience 2015, 286, 45-59. [CrossRef]

48. Retamal, M.A.; Froger, N.; Palacios-Prado, N.; Ezan, P.; Sáez, P.J.; Sáez, J.C.; Giaume, C. Cx43 hemichannels and gap junction channels in astrocytes are regulated oppositely by proinflammatory cytokines released from activated microglia. J. Neurosci. 2007, 27, 13781-13792. [CrossRef]

49. Locovei, S.; Wang, J.; Dahl, G. Activation of pannexin 1 channels by ATP through P2Y receptors and by cytoplasmic calcium. FEBS Lett. 2006, 580, 239-244. [CrossRef]

50. Baroja-Mazo, A.; Barberà-Cremades, M.; Pelegrín, P. The participation of plasma membrane hemichannels to purinergic signaling. Biochim. Biophys. Acta Biomembr. 2013, 1828, 79-93. [CrossRef]

51. Rovegno, M.; Saez, J.C. Role of astrocyte connexin hemichannels in cortical spreading depression. Biochim. Biophys. Acta Biomembr. 2018, 1860, 216-223. [CrossRef] [PubMed]

52. De Vuyst, E.; Decrock, E.; De Bock, M.; Yamasaki, H.; Naus, C.C.; Evans, W.H.; Leybaert, L. Connexin hemichannels and gap junction channels are differentially influenced by lipopolysaccharide and basic fibroblast growth factor. Mol. Biol. Cell. 2007, 18, 34-46. [CrossRef] [PubMed]

53. Mallard, C.; Davidson, J.O.; Tan, S.; Green, C.R.; Bennet, L.; Robertson, N.J.; Gunn, A.J. Astrocytes and microglia in acute cerebral injury underlying cerebral palsy associated with preterm birth. Pediatr. Res. 2014, 75, 234-240. [CrossRef] [PubMed]

54. Hung, S.C.; Choi, C.H.; Said-Sadier, N.; Johnson, L.; Atanasova, K.R.; Sellami, H.; Yilmaz, O.; Ojcius, D.M. P2X4 assembles with P2X7 and pannexin-1 in gingival epithelial cells and modulates ATP-induced reactive oxygen species production and inflammasome activation. PLoS ONE 2013, 8, e70210. [CrossRef]

55. Sutterwala, F.S.; Haasken, S.; Cassel, S.L. Mechanism of NLRP3 inflammasome activation. Ann. N. Y. Acad. Sci. 2014, 1319, 82-95. [CrossRef]

56. Gombault, A.; Baron, L.; Couillin, I. ATP release and purinergic signaling in NLRP3 inflammasome activation. Front. Immunol. 2012, 3, 414. [CrossRef]

57. Murakami, T.; Ockinger, J.; Yu, J.; Byles, V.; McColl, A.; Hofer, A.M.; Horng, T. Critical role for calcium mobilization in activation of the NLRP3 inflammasome. Proc. Natl. Acad. Sci. USA 2012, 109, 11282-11287. [CrossRef]

58. Riteau, N.; Baron, L.; Villeret, B.; Guillou, N.; Savigny, F.; Ryffel, B.; Rassendren, F.; Le Bert, M.; Gombault, A.; Couillin, I. ATP release and purinergic signaling: A common pathway for particle-mediated inflammasome activation. Cell Death Dis. 2012, 3, e403. [CrossRef] 
59. Weber, M.D.; Frank, M.G.; Tracey, K.J.; Watkins, L.R.; Maier, S.F. Stress induces the danger-associated molecular pattern HMGB-1 in the hippocampus of male Sprague Dawley rats: A priming stimulus of microglia and the NLRP3 inflammasome. J. Neurosci. 2015, 35, 316-324. [CrossRef]

60. Zou, J.; Crews, F. Glutamate/NMDA excitotoxicity and HMGB1/TLR4 neuroimmune toxicity converge as components of neurodegeneration. AIMS Public Health 2015, 2, 77-100. [CrossRef]

61. Silverman, W.R.; de Rivero Vaccari, J.P.; Locovei, S.; Qiu, F.; Carlsson, S.K.; Scemes, E.; Keane, R.W.; Dahl, G. The pannexin 1 channel activates the inflammasome in neurons and astrocytes. J. Biol. Chem. 2009, 284, 18143-18151. [CrossRef] [PubMed]

62. Liddelow, S.A.; Barres, B.A. Reactive astrocytes: Production, Function, and Therapeutic Potential. Immunity 2017, 46, 957-967. [CrossRef]

63. Allnoch, L.; Baumgärtner, W.; Hansmann, F. Impact of Astrocyte Depletion upon Inflammation and Demyelination in a Murine Animal Model of Multiple Sclerosis. Int. J. Mol. Sci. 2019, 20, 3922. [CrossRef] [PubMed]

64. Sofroniew, M.V.; Vinters, H.V. Astrocytes: Biology and pathology. Acta Neuropathol. 2010, 119, 7-35. [CrossRef] [PubMed]

65. Ludwin, S.K.; Rao, V.; Moore, C.S.; Antel, J.P. Astrocytes in multiple sclerosis. Mult. Scler. J. 2016, 22, 1114-1124. [CrossRef]

66. Liddelow, S.A.; Guttenplan, K.A.; Clarke, L.E.; Bennett, F.C.; Bohlen, C.J.; Schirmer, L.; Bennett, M.L.; Munch, A.E.; Chung, W.S.; Peterson, T.C. Neurotoxic reactive astrocytes are induced by activated microglia. Nature 2017, 541, 481-487. [CrossRef]

67. Herz, J.; Filiano, A.J.; Smith, A.; Yogev, N.; Kipnis, J. Myeloid Cells in the Central Nervous System. Immunity 2017, 46, 943-956. [CrossRef]

68. Klein, R.S.; Hunter, C.A. Protective and Pathological Immunity during Central Nervous System Infections. Immunity 2017, 46, 891-909. [CrossRef]

69. Zamanian, J.L.; Xu, L.; Foo, L.C.; Nouri, N.; Zhou, L.; Giffard, R.G.; Barres, B.A. Genomic Analysis of Reactive Astrogliosis. J. Neurosci. 2012, 32, 6391-6410. [CrossRef]

70. Heppner, F.L.; Ransohoff, R.M.; Becher, B. Immune attack: The role of inflammation in Alzheimer disease. Nat. Rev. Neurosci. 2015, 16, 358-372. [CrossRef]

71. Sáez, J.C.; Schalper, K.A.; Retamal, M.A.; Orellana, J.A.; Shoji, K.F.; Bennett, M.V. Cell membrane permeabilization via connexin hemichannels in living and dying cells. Exp. Cell Res. 2010, 316, 2377-2389. [CrossRef] [PubMed]

72. Bezzi, P.; Volterra, A. A neuron-glia signalling network in the active brain. Curr. Opin. Neurobiol. 2001, 11, 387-394. [CrossRef]

73. Anderson, M.A.; Burda, J.E.; Ren, Y.; Ao, Y.; O’Shea, T.M.; Kawaguchi, R.; Coppola, G.; Khakh, B.S.; Deming, T.J.; Sofroniew, M.V. Astrocyte scar formation aids CNS axon regeneration. Nature 2016, 532, 195-200. [CrossRef]

74. Kang, J.; Kang, N.; Lovatt, D.; Torres, A.; Zhao, Z.; Lin, J.; Nedergaard, M. Connexin 43 Hemichannels Are Permeable to ATP. J. Neurosci. 2008, 28, 4702-4711. [CrossRef] [PubMed]

75. Lian, H.; Yang, L.; Cole, A.; Sun, L.; Chiang, A.C.-A.; Fowler, S.W.; Shim, D.J.; Rodriguez-Rivera, J.; Taglialatela, G.; Jankowsky, J.L.; et al. NFkB-activated Astroglial Release of Complement C3 Compromises Neuronal Morphology and Function Associated with Alzheimer's Disease. Neuron 2015, 85, 101-115. [CrossRef] [PubMed]

76. Wang, L.; Pei, S.; Han, L.; Guo, B.; Li, Y.; Duan, R.; Yao, Y.; Xue, B.; Chen, X.; Jia, Y. Mesenchymal Stem Cell-Derived Exosomes Reduce A1 Astrocytes via Downregulation of Phosphorylated NFKB P65 Subunit in Spinal Cord Injury. Cell. Physiol. Biochem. 2018, 50, 1535-1559. [CrossRef]

77. Shen, Y.; Qin, H.; Chen, J.; Mou, L.; He, Y.; Yan, Y.; Zhou, H.; Lv, Y.; Chen, Z.; Wang, J.; et al. Postnatal activation of TLR4 in astrocytes promotes excitatory synaptogenesis in hippocampalneurons. J. Cell Biol. 2016, 215, 719-734. [CrossRef]

78. Papaneophytou, C.; Georgiou, E.; Kleopa, K.A. The role of oligodendrocyte gap junctions in neuroinflammation. Channels 2019, 13, 247-263. [CrossRef]

79. del Río-Hortega, P. Son homologables la glía de escasas radiaciones y la celuladeSchwann. Bol. Soc. Esp. Biol. $1922,10,25-28$. 
80. Battefeld, A.; Klooster, J.; Kole, M.H. Myelinating satellite oligodendrocytes are integrated in a glial syncytium constraining neuronal high-frequency activity. Nat. Commun. 2016, 7, 11298. [CrossRef]

81. Philips, T.; Rothstein, J.D. Oligodendroglia: Metabolic supporters of neurons. J. Clin. Investig. 2017, 127, 3271-3280. [CrossRef] [PubMed]

82. Magnotti, L.M.; Goodenough, D.A.; Paul, D.L. Deletion of oligodendrocyte Cx32 and astrocyte Cx43 causeswhite matter vacuolation, astrocyte loss and early mortality. Glia 2011, 59, 1064-1074. [CrossRef]

83. Vejar, S.; Oyarzún, J.E.; Retamal, M.A.; Ortiz, F.C.; Orellana, J.A. Connexin and Pannexin-Based Channels in Oligodendrocytes: Implications in Brain Health and Disease. Front. Cell. Neurosci. 2019, 13, 3. [CrossRef] [PubMed]

84. Georgiou, E.; Sidiropoulou, K.; Richter, J. Gene therapy targeting oligodendrocytes provides therapeutic benefit in a leukodystrophy model. Brain 2017, 140, 599-616. [CrossRef] [PubMed]

85. Lawson, L.J.; Perry, V.H.; Dri, P.; Gordon, S. Heterogeneity in the distribution and morphology of microglia in the normal adult mouse brain. Neuroscience 1990, 39, 151-170. [CrossRef]

86. Kettenmann, H.; Hanisch, U.K.; Noda, M.; Verkhratsky, A. Physiology of Microglia. Physiol. Rev. 2011, 91, 461-553. [CrossRef]

87. Brionne, T.C.; Tesseur, I.; Masliah, E.; Wyss-Coray, T. Loss of TGF-beta 1 leads to increased neuronal cell death and microgliosis in mouse brain. Neuron 2003, 40, 1133-1145. [CrossRef]

88. Basilico, B.; Pagani, F.; Grimaldi, A.; Cortese, B.; Di Angelantonio, S.; Weinhard, L.; Gross, C.; Limatola, C.; Maggi, L.; Ragozzino, D. Microglia shape presynaptic properties at developing glutamatergic synapses. Glia 2019, 67, 53-67. [CrossRef]

89. Wu, Y.; Dissing-Olesen, L.; MacVicar, B.A.; Stevens, B. Microglia: Dynamic Mediators of Synapse Development and Plasticity. Trends Immunol. 2015, 36, 605-613. [CrossRef]

90. Schafer, D.P.; Lehrman, E.K.; Stevens, B. "quad-partite" synapse: Microglia-synapse interactions in the developing and mature CNS. Glia 2013, 61, 24-36. [CrossRef]

91. Wake, H.; Moorhouse, A.J.; Miyamoto, A.; Nabekura, J. Microglia: Actively surveying and shaping neuronal circuit structure and function. Trends Neurosci. 2013, 36, 209-217. [CrossRef] [PubMed]

92. Ikegami, A.; Haruwaka, K.; Wake, H. Microglia: Lifelong modulator of neural circuits. Neuropathology 2019, 39, 173-180. [CrossRef] [PubMed]

93. Maezawa, I.; Jin, L.W. Rett Syndrome Microglia Damage Dendrites and Synapses by the Elevated Release of Glutamate. J. Neurosci. 2010, 30, 5346-5356. [CrossRef] [PubMed]

94. Parenti, R.; Campisi, A.; Vanella, A.; Cicirata, F. Immunocytochemical and RT-PCR analysis of connexin36 in cultures of mammalian glial cells. Arch. Ital. Biol. 2002, 140, 101-108. [PubMed]

95. Belousov, A.B.; Nishimune, H.; Denisova, J.V.; Fontes, J.D. A potential role for neuronal connexin 36 in the pathogenesis of amyotrophic lateral sclerosis. Neurosci. Lett. 2018, 666, 1-4. [CrossRef] [PubMed]

96. Richter, N.; Wendt, S.; Georgieva, P.B.; Hambardzumyan, D.; Nolte, C.; Kettenmann, H. Glioma-associated microglia and macrophages/monocytes display distinct electrophysiological properties and do not communicate via gap junctions. Neurosci. Lett. 2014, 583, 130-135. [CrossRef]

97. Rouach, N.; Avignone, E.; Même, W.; Koulakoff, A.; Venance, L.; Blomstrand, F.; Giaume, C. Gap junctions and connexin expression in the normal and pathological central nervous system. Biol. Cell 2002, 94, 457-475. [CrossRef]

98. Sáez, P.J.; Shoji, K.F.; Retamal, M.A.; Harcha, P.A.; Ramírez, G.; Jiang, J.X.; von Bernhardi, R.; Sáez, J.C. ATP is required and advances cytokine-induced gap junction formation in microglia in vitro. Mediat. Inflamm. 2013, 2013, 216402. [CrossRef]

99. Gaikwad, S.; Patel, D.; Agrawal-Rajput, R. CD40 Negatively Regulates ATP-TLR4-Activated Inflammasome in Microglia. Cell. Mol. Neurobiol. 2017, 37, 351-359. [CrossRef]

100. Bona, E.; Andersson, A.L.; Blomgren, K.; Gilland, E.; Puka-Sundvall, M.; Gustafson, K.; Hagberg, H. Chemokine and Inflammatory Cell Response to Hypoxia-Ischemia in Immature Rats. Pediatr. Res. 1999, 45, 500-509. [CrossRef]

101. Benson, M.; Manzanero, J.S.; Borges, K. Complex alterations in microglial M1/M2 markers during the development of epilepsy in two mouse models. Epilepsia 2015, 56, 895-905. [CrossRef]

102. Wolf, S.A.; Boddeke, H.W.; Kettenmann, H. Microglia in Physiology and Disease. Annu. Rev. Physiol. 2017, 79, 619-643. [CrossRef] 
103. Takeuchi, H.; Jin, S.; Wang, J.; Zhang, G.; Kawanokuchi, J.; Kuno, R.; Sonobe, Y.; Mizuno, T.; Suzumura, A. Tumor Necrosis Factor- $\alpha$ Induces neurotoxicity via Glutamate Release from Hemichannels of Activated Microglia in an Autocrine Manner. J. Biol. Chem. 2006, 281, 21362-21368. [CrossRef]

104. Orellana, J.A.; Froger, N.; Ezan, P.; Jiang, J.X.; Bennett, M.V.; Naus, C.C.; Giaume, C.; Sáez, J.C. ATP and glutamate released via astroglial connexin 43 hemichannels mediate neuronal death through activation of pannexin 1 hemichannels. J. Neurochem. 2011, 118, 826-840. [CrossRef]

105. Domercq, M.; Perez-Samartin, A.; Aparicio, D.; Alberdi, E.; Pampliega, O.; Matute, C. P2X7 receptors mediate ischemic damage to oligodendrocytes. Glia 2010, 58, 730-740. [CrossRef]

106. Engel, T.; Alves, M.; Sheedy, C.; Henshall, D.C. ATPergic signalling during seizures and epilepsy. Neuropharmacology 2016, 104, 140-153. [CrossRef]

107. Baron, L.; Gombault, A.; Fanny, M.; Villeret, B.; Savigny, F.; Guillou, N.; Panek, C.; Le Bert, M.; Lagente, V.; Rassendren, F; et al. The NLRP3 inflammasome is activated by nanoparticles through ATP, ADP and adenosine. Cell Death Dis. 2015, 6, e1629. [CrossRef]

108. Heneka, M.T.; McManus, R.M.; Latz, E. Inflammasome signalling in brain function and neurodegenerative disease. Nat. Rev. Neurosci. 2018, 19, 610-621. [CrossRef]

109. Voet, S.; Srinivasan, S.; Lamkanfi, M.; van Loo, G. Inflammasomes in neuroinflammatory and neurodegenerative diseases. EMBO Mol. Med. 2019, 11, e10248. [CrossRef]

110. Rong, S.; Wan, D.; Fan, Y.; Liu, S.; Sun, K.; Huo, J.; Zhang, P.; Li, X.; Xie, X.; Wang, F.; et al. Amentoflavone Affects Epileptogenesis and Exerts Neuroprotective Effects by Inhibiting NLRP3 Inflammasome. Front. Pharmacol. 2019, 10, 856. [CrossRef]

111. Tapia, R.; Medina-Ceja, L.; Peña, F. Action of 4-aminopyridine on extracellular amino acids in hippocampus and entorhinal cortex: A dual microdialysis and electroencehalographic study in awake rats. Brain Res. Bull. 2000, 53, 255-262.

112. Condorelli, D.F.; Conti, F.; Gallo, V.; Kirchhoff, F.; Seifert, G.; Steinhauser, C.; Verkhratsky, A.; Yuan, X. Expression and functional analysis of glutamate receptors in glial cells. Adv. Exp. Med. Biol. 1999, 468, 49-67.

113. Seifert, G.; Steinhauser, C. Ionotropic glutamate receptors in astrocytes. Prog. Brain Res. 2001, 132, $287-299$.

114. Verkhratsky, A.; Kirchhoff, F. Glutamate-mediated neuronal-glial transmission. J. Anat. 2007, 210, 651-660. [CrossRef]

115. Hamzei-Sichani, F.; Kamasawa, N.; Janssen, W.G.; Yasumura, T.; Davidson, K.G.; Hof, P.R.; Wearne, S.L.; Stewart, M.G.; Young, S.R.; Whittington, M.A.; et al. Gap junctions on hippocampal mossy fiber axons demonstrated by thin-section electron microscopy and freeze fracture replica immunogold labeling. Proc. Natl. Acad. Sci. USA 2007, 104, 12548-12553. [CrossRef]

116. Traub, R.D.; Draguhn, A.; Whittington, M.A.; Baldeweg, T.; Bibbig, A.; Buhl, E.H.; Schmitz, D. Axonal gap junctions between principal neurons: A novel source of network oscillations, and perhaps epileptogenesis. Rev. Neuroci. 2002, 13, 1-30. [CrossRef]

117. Traub, R.D.; Whittington, M.A.; Gutiérrez, R.; Draguhn, A. Electrical coupling between hippocampal neurons: Contrasting roles of principal cell gap junctions and interneuron gap junctions. Cell Tissue Res. 2018, 373, 671-691. [CrossRef]

118. Mathy, A.; Clark, B.A.; Häusser, M. Synaptically induced long-term modulation of electrical coupling in the inferior olive. Neuron 2014, 81, 1290-1296. [CrossRef]

119. Turecek, J.; Yuen, G.S.; Han, V.Z.; Zeng, X.H.; Bayer, K.U.; Welsh, J.P. NMDA receptor activation strengthens weak electrical coupling in mammalian brain. Neuron 2014, 81, 1375-1388. [CrossRef]

120. Siesjö, B.K.; von Hanwehr, R.; Nergelius, G.; Nevander, G.; Ingvar, M. Extra- and intracellular pH in the brain during seizures and in the recovery period following the arrest of seizure activity. J. Cereb. Blood Flow Metab. 1985, 5, 47-57. [CrossRef]

121. Schalper, K.A.; Sánchez, H.A.; Lee, S.C.; Altenberg, G.A.; Nathanson, M.H.; Sáez, J.C. Connexin 43 hemichannels mediate the Ca2+ influx induced by extracellular alkalinization. Am. J. Physiol. Cell Physiol. 2010, 299, C1504-C1515. [CrossRef]

122. Palacios-Prado, N.; Briggs, S.W.; Skeberdis, V.A.; Pranevicius, M.; Bennett, M.V.; Bukauskas, F.F. $\mathrm{pH}$-dependent modulation of voltage gating in connexin45 homotypic and connexin45/connexin43 heterotypic gap junctions. Proc. Natl. Acad. Sci. USA 2010, 107, 9897-9902. [CrossRef]

123. Pogoda, K.; Kameritsch, P.; Retamal, M.A.; Vega, J.L. Regulation of gap junction channels and hemichannels by phosphorylation and redox changes: A revision. BMC Cell Biol. 2016, 17 (Suppl. 1), 11. [CrossRef] 
124. Garciarena, C.D.; Malik, A.; Swietach, P.; Moreno, A.P.; Vaughan-Jones, R.D. Distinct moieties underlie biphasic $\mathrm{H}_{+}$gating of connexin43 channels, producing a $\mathrm{pH}$ optimum for intercellular communication. FASEB J. 2018, 32, 1969-1981. [CrossRef]

125. Gajda, Z.; Szupera, Z.; Blazsó, G.; Szente, M. Quinine, a blocker of neuronal cx36 channels, suppresses seizure activity in rat neocortex in vivo. Epilepsia 2005, 46, 1581-1591. [CrossRef]

126. Nilsen, K.E.; Kelso, A.R.; Cock, H.R. Antiepileptic effect of gap-junction blockers in a rat model of refractory focal cortical epilepsy. Epilepsia 2006, 47, 1169-1175. [CrossRef]

127. Bostanci, M.O.; Bağirici, F. Anticonvulsive effects of carbenoxolone on penicillin-induced epileptiform activity: An in vivo study. Neuropharmacology 2007, 52, 362-367. [CrossRef]

128. Medina-Ceja, L.; Cordero-Romero, A.; Morales-Villagrán, A. Antiepileptic effect of carbenoxolone on seizures induced by 4-aminopyridine: A study in the rat hippocampus and entorhinal cortex. Brain Res. 2008, 1187, 74-81. [CrossRef]

129. Medina-Ceja, L.; Ventura-Mejía, C. Differential effects of trimethylamine and quinine on seizures induced by 4-aminopyridine administration in the entorhinal cortex of vigilant rats. Seizure 2010, 19, 507-513. [CrossRef]

130. Chen, W.; Gao, Z.; Ni, Y.; Dai, Z. Carbenoxolone pretreatment and treatment of posttraumatic epilepsy. Neural Regen. Res. 2013, 8, 169-176.

131. Sefil, F.; Arık, A.E.; Acar, M.D.; Bostanc1, M.Ö.; Bagirici, F.; Kozan, R. Interaction between carbenoxolone and valproic acid on pentylenetetrazole kindling model of epilepsy. Int. J. Clin. Exp. Med. 2015, 8, 10508-10514.

132. Franco-Pérez, J.; Manjarrez-Marmolejo, J.; Rodríguez-Balderas, C.; Castro, N.; Ballesteros-Zebadua, P. Quinine and carbenoxolone enhance the anticonvulsant activity of some classical antiepileptic drugs. Neurol. Res. 2018, 40, 26-33. [CrossRef]

133. Szente, M.; Gajda, Z.; Said, A.K.; Hermesz, E. Involvement of electrical coupling in the in vivo ictal epileptiform activity induced by 4-aminopyridine in the neocortex. Neuroscience 1067. [CrossRef]

134. Davidson, J.S.; Baumgarten, I.M. Glycyrrhetinic acid derivatives: A novel class of inhibitors of gap-junctional intercellular communication. Structure-activity relationships. J. Pharmacol. Exp. Ther. 1988, 246, 1104-1107.

135. Goldberg, G.S.; Moreno, A.P.; Bechberger, J.F.; Hearn, S.S.; Shivers, R.R.; MacPhee, D.J.; Zhang, Y.C.; Naus, C.C. Evidence that disruption of connexon particle arrangements in gap junction plaques is associated with inhibition of gap junctional communication by a glycyrrhetinic acid derivative. Exp. Cell Res. 1996, 222, 48-53. [CrossRef]

136. Guan, X.; Wilson, S.; Schlender, K.K.; Ruch, R.J. Gap-junction disassembly and connexin 43 dephosphorylation induced by 18 beta-glycyrrhetinic acid. Mol. Carcinog. 1996, 16, 157-164. [CrossRef]

137. Yin, X.; Feng, L.; Ma, D.; Yin, P.; Wang, X.; Hou, S.; Hao, Y.; Zhang, J.; Xin, M.; Feng, J. Roles of astrocytic connexin-43, hemichannels, and gap junctions in oxygen-glucose deprivation/reperfusion injury induced neuroinflammation and the possible regulatory mechanisms of salvianolic acid B and carbenoxolone. J. Neuroinflamm. 2018, 15, 97. [CrossRef]

138. Walden, J.; Speckmann, E.J. Effects of quinine on membrane potential and membrane currents in identified neurons of Helix pomatia. Neurosci. Lett. 1981, 27, 139-143. [CrossRef]

139. Cherubini, E.; North, R.A.; Surprenant, A. Quinine blocks a calcium-activated potassium conductance in mammalian enteric neurones. Br. J. Pharmacol. 1984, 83, 3-5. [CrossRef]

140. Srinivas, M.; Hopperstad, M.G.; Spray, D.C. Quinine blocks specific gap junction channel subtypes. Proc. Natl. Acad. Sci. USA 2001, 98, 10942-10947. [CrossRef]

141. Zou, L.; Xue, Y.; Jones, M.; Heinbockel, T.; Ying, M.; Zhan, X. The Effects of Quinine on Neurophysiological Properties of Dopaminergic Neurons. Neurotox. Res. 2018, 34, 62-73. [CrossRef]

142. Thompson, A.J.; Lummis, S.C. Antimalarial drugs inhibit human 5-HT(3) and GABA(A) but not GABA(C) receptors. Br. J. Pharmacol. 2008, 153, 1686-1696. [CrossRef]

143. Coker, S.J.; Batey, A.J.; Lightbown, I.D.; Díaz, M.E.; Eisner, D.A. Effects of mefloquine on cardiac contractility and electrical activity in vivo, in isolated cardiac preparations, and in single ventricular myocytes. Br. J. Pharmacol. 2000, 129, 323-330. [CrossRef]

144. Heshmati, M.; Golden, S.A.; Pfau, M.L.; Christoffel, D.J.; Seeley, E.L.; Cahill, M.E.; Khibnik, L.A.; Russo, S.J. Mefloquine in the nucleus accumbens promotes social avoidance and anxiety-like behavior in mice. Neuropharmacology 2016, 101, 351-357. [CrossRef]

145. Evans, W.H.; Bultynck, G.; Leybaert, L. Manipulating connexin communication channels: Use of peptidomimetics and the translational outputs. J. Membr. Biol. 2012, 245, 437-449. [CrossRef] 
146. Samoilova, M.; Wentlandt, K.; Adamchik, Y.; Velumian, A.A.; Carlen, P.L. Connexin 43 mimetic peptides inhibit spontaneous epileptiform activity in organotypic hippocampal slice cultures. Exp. Neurol. 2008, 210, 762-775. [CrossRef]

147. Yoon, J.J.; Green, C.R.; O'Carroll, S.J.; Nicholson, L.F. Dose dependent protective effect of connexin43 mimetic peptide against neurodegeneration in an ex vivo model of epileptiform lesion. Epilepsy Res. 2010, 92, 153-162. [CrossRef]

148. Bragin, A.; Wilson, C.L.; Engel, J., Jr. Chronic epileptogenesis requires development of a network of pathologically interconnected neuron clusters: A hypothesis. Epilepsia 2000, 41 (Suppl. 6), S144-S152. [CrossRef]

149. Bragin, A.; Mody, I.; Wilson, C.L.; Engel, J., Jr. Local generation of fast ripples in epileptic brain. J. Neurosci. 2002, 22, 2012-2021. [CrossRef]

150. Ventura-Mejía, C.; Medina-Ceja, L. Decreased fast ripples in the hippocampus of rats with spontaneous recurrent seizures treated with carbenoxolone and quinine. BioMed Res. Int. 2014, 2014, 282490. [CrossRef]

151. Ran, X.; Xiang, J.; Song, P.P.; Jiang, L.; Liu, B.K.; Hu, Y. Effects of gap junctions blockers on fast ripples and connexin in rat hippocampi after status epilepticus. Epilepsy Res. 2018, 146, 28-35. [CrossRef]

152. Simon, A.; Traub, R.D.; Vladimirov, N.; Jenkins, A.; Nicholson, C.; Whittaker, R.G.; Schofield, I.; Clowry, G.J.; Cunningham, M.O.; Whittington, M.A. Gap junction networks can generate both ripple-like and fast ripple-like oscillations. Eur. J. Neurosci. 2014, 39, 46-60. [CrossRef]

153. Gigout, S.; Louvel, J.; Kawasaki, H.; D’Antuono, M.; Armand, V.; Kurcewicz, I.; Olivier, A.; Laschet, J.; Turak, B.; Devaux, B.; et al. Effects of gap junction blockers on human neocortical synchronization. Neurobiol. Dis. 2006, 22, 496-508. [CrossRef]

154. Nikolic, L.; Shen, W.; Nobili, P.; Virenque, A.; Ulmann, L.; Audinat, E. Blocking TNF $\alpha$-driven astrocyte purinergic signaling restores normal synaptic activity during epileptogenesis. Glia 2018, 66, 2673-2683. [CrossRef]

155. Wang, Y.; Denisova, J.V.; Kang, K.S.; Fontes, J.D.; Zhu, B.T.; Belousov, A.B. Neuronal gap junctions are required for NMDA receptor-mediated excitotoxicity: Implications in ischemic stroke. J. Neurophysiol. 2010, 104, 3551-3556. [CrossRef]

156. Fellin, T.; Pascual, O.; Gobbo, S.; Pozzan, T.; Haydon, P.G.; Carmignoto, G. Neuronal synchrony mediated by astrocytic glutamate through activation of extrasynaptic NMDA receptors. Neuron 2004, 43, 729-743. [CrossRef]

157. Xing, L.; Yang, T.; Cui, S.; Chen, G. Connexin hemichannels in astrocytes: Role in CNS disorders. Front. Mol. Neurosci. 2019, 12, 23. [CrossRef]

158. Rouach, N.; Koulakoff, A.; Abudara, V.; Willecke, K.; Giaume, C. Astroglial metabolic networks sustain hippocampal synaptic transmission. Science 2008, 322, 1551-1555. [CrossRef]

159. Vincze, R.; Péter, M.; Szabó, Z.; Kardos, J.; Héja, L.; Kovács, Z. Connexin 43 Differentially Regulates Epileptiform Activity in Models of Convulsive and Non-convulsive Epilepsies. Front. Cell. Neurosci. 2019, 13, 173. [CrossRef]

160. Walrave, L.; Pierre, A.; Albertini, G.; Aourz, N.; De Bundel, D.; Van Eeckhaut, A.; Vinken, M.; Giaume, C.; Leybaert, L.; Smolders, I. Inhibition of astroglial connexin 43 hemichannels with TAT-Gap19 exerts anticonvulsant effects in rodents. Glia 2018, 66, 1788-1804. [CrossRef]

(C) 2019 by the authors. Licensee MDPI, Basel, Switzerland. This article is an open access article distributed under the terms and conditions of the Creative Commons Attribution (CC BY) license (http://creativecommons.org/licenses/by/4.0/). 